\title{
АКТИВНІСТЬ ЗАПАЛЬНИХ ТА ЦИТОЛІТИЧНИХ ПРОЦЕСІВ У ЩУРІВ РІЗНОГО ВІКУ В ДИНАМІЦІ УРАЖЕННЯ ТЮТЮНОВИМ ДИМОМ
}

\section{Активність запальних та цитолітичних процесів у щурів різного віку в динаміці ураження тютюновим димом}

П. Г. Лихацький, В. Д. Фіра, Х. М. Сурман, Д. Б. Фіра

Тернопільський національний медичний університет імені І. Я. Горбачевського мОЗ України

Резюме. Аналіз великої кількості робіт за останні десятиліття, присвячених впливу куріння на організм здорової людини, свідчить, що немає такого органа або системи в організмі, на які б воно не мало шкідливої дії. Тютюнокуріння $\epsilon$ агресивним орактором ризику виникнення та прогресування груп захворювань, серед яких рак легенів, ішемічна хвороба серця, артеріальна гіпертензія, остеопороз і деякі інші. Однак до останнього часу в літературі зустрічалася незначна кількість експериментальних робіт, в яких би досліджувався вплив тютюнового диму на організм у віковому аспекті, зокрема на окиснювальні та запальні процеси, проникність клітинних мембран та стан ендогенної інтоксикації, що сприяло б пошуку нових обгрунтованих способів корекції.

Мета дослідження - з'ясувати вплив тютюнового диму на розвиток запалення та проникність клітинних мембран у щурів різного віку за тютюнової інтоксикації.

Матеріали і методи. Досліди проведені на білих щурах-самцях, яких утримували на стандартному раціоні віварію Тернопільського національного медичного університету імені І. Я. Горбачевського МОЗ України. щурів поділили на три вікові групи: статевонезрілі, статевозрілі та старечого віку. Модель залежності від хронічної дії тютюнового диму створювали за допомогою герметичної камери. Тютюновий дим, що утворювався від горіння 6 сигарет «Прима срібна (синя)» із вмістом 0,6 мг нікотину та 8 мг смоли, через отвори у камері подавався всередину. Через 15; 30 та 45 діб від початку ураження тварин тютюновим димом, їх виводили з експерименту. В сироватці крові та тканинах визначали вміст С-реактивного протеїну, активність лужної фросоратази та гаммаглутамілтранспептидази.

Результати. У щурів різного віку спостерігалось підвищення вмісту С-реактивного протеїну в сироватці крові протягом 45 діб отруєння тютюновим димом. Найчутливішими до дії токсиканта виявились старечі щури, у яких даний показник прогресуюче зростав і до кінця експерименту перевищував рівень контрольної групи в 1,4 раза. Поряд з цим у тварин усіх вікових груп (статевонезрілі, статевозрілі та старечі) відмічалось
Activity of inflammatory and cytolytic processes in rats of different ages in the dynamics of tobacco smoke

P. H. Lykhatskyi, V. D. Fira, H. M. Surman, D. B. Fira I. Horbachevsky Ternopil National Medical University

e-mail: luhatsky@tdmu.edu.ua

Summary. Analysis of a large number of works in recent decades on the effects of smoking on the body of a healthy person, shows that there is no organ or system in the body on which smoking would not have a harmful effect. Smoking is an aggressive risk factor for the occurrence and progression of groups of diseases, including lung cancer, coronary heart disease, hypertension, osteoporosis and some others. However, until recently, there was a small amount of experimental work in the literature to study the effects of tobacco smoke on the body in terms of age, including oxidative and inflammatory processes, permeability of cell membranes and endogenous intoxication, which would help find new reasonable ways to correct.

The aim of the study was to determine the effect of tobacco smoke on the development of inflammation and permeability of cell membranes in rats of different ages in tobacco intoxication.

Materials and methods. The experiments were performed on white male rats kept on the standard diet of the TSMU vivarium. Rats were divided into three age groups: immature, mature and senile. The model of dependence on the chronic effects of tobacco smoke was created using a sealed chamber. Tobacco smoke, formed from the burning of 6 Prima Silver (blue) cigarettes containing $0.6 \mathrm{mg}$ of nicotine and $8 \mathrm{mg}$ of tar, was fed into the chamber through openings. After 15, 30 and 45 days from the beginning of the defeat of the animals with tobacco smoke, they were removed from the experiment. In serum and tissue levels of C-reactive protein, alkaline phosphatase and gamma-glutamyltranspeptidase activity were determined.

Results. In rats of different ages, an increase in serum $C$-reactive protein was observed during 45 days of tobacco smoke poisoning. The most sensitive to the action of the toxicant were senile rats, in which this indicator progressively increased and by the end of the experiment exceeded the level of the control group by 1.4 times. In addition, in animals of all ages (immature, mature and senile) there was an increase in alkaline phosphatase activity in serum and its decrease in the liver, which confirms the development of cholestasis and membrane-destructive processes in the 
підвищення активності лужної фоосфатази у сироватці крові та зниження їі у печінці, що підтверджує розвиток холестазу та мембранодеструктивних процесів у печінці токсикованих тварин. На останнє вказує підвищення активності у сироватці крові мембранозалежного ензиму гаммаглутамілтранспептидази протягом усього експерименту. До кінця дослідження вона зросла у статевонезрілих щурів у 1,9 раза, статевозрілих - в 1,35 раза та у старечих - в 1,6 раза. Найбільш виражені зміни проникності клітинних мембран спостерігались у статевонезрілих тварин.

Висновки. У старечих щурів запальні прочеси прогресували найбільш виражено, підтвердженням чому підвищення вмісту C-реактивного протеїну в сироватці крові. У статевонезрілих щурів відмічено прогресуюче підвищення активності мембранозалежних ензимів (гаммаглутамілтранспептидази та лужної фоосфратази) у сироватці крові після отруєння тютюновим димом, яке до кінця експерименту значно перевищувало рівень щурів статевозрілого та старечого віку. Це дозволяє стверджувати, що статевонезрілі щури більш чутливі до впливу на них тютюнового диму.

Ключові слова: тютюновий дим; білі щури; запальні процеси; цитолітичні процеси.

\section{ВСТУП}

Україна належить до країн із високою поширеністю тютюнокуріння. Сьогодні в нашій країні курить кожен другий чоловік і кожна п'ята жінка. Тютюнокуріння залишається однією з основних причин неінфекційних хвороб, серед яких інфаркт, інсульт, рак, діабет 2 типу [1-4].

Активний і пасивний тютюновий дим призводить до зміни срункцій ендотелію судин, що залежить від отриманої дози диму. 3 одного боку, це пов'язано з утворенням та високим вмістом активних форм оксигену (АФО), з іншого - із розвитком запальних процесів в організмі [5-7].

Багато літературних даних вказують на те, що тютюновий дим може викликати запальні процеси, зокрема за допомогою індукції прозапальних цитокінів [8, 9]. Рівні кількох маркерів запалення, включаючи С-реактивний протеїн (СРП), інтерлейкін-6 та фрактор некрозу пухлини, збільшуються в курців $[10,11]$

Дослідження вмісту СРПє одним із найбільш прийнятних маркерів ранньої діагностики та моніторингу запального захворювання [12]. СРП представник зразу декількох фрункціональних груп: медіаторів, транспортних протеїнів, імуномодуляторів. Він є високочутливим, але неспецисрічним гострофразовим показником, котрий продукується у відповідь на більшість фрорм тканинного ушкодження, інфеекцію чи запалення і з'являється в плазмі крові через 4-6 год після ураження тканини різними чинниками $[13,14]$.

Найесрективніше ступінь ураження клітинних мембран відображається співвідношенням ак- liver of toxic animals. The latter indicates an increase in the activity in the serum of the membrane-dependent enzyme gamma-glutamyltranspeptidase throughout the experiment. By the end of the study, it had increased 1.9-fold in immature rats, 1.35-fold in mature rats, and 1.6-fold in senile rats. The most pronounced changes in cell membrane permeability were observed in immature animals.

Conclusions. In senile rats, inflammatory processes progressed most markedly, as evidenced by the most pronouncedincrease in serum C-reactive protein. In immature rats, a progressive increase in the activity of membranedependent enzymes (gamma-glutamyltranspeptidase and alkaline phosphatase) in the serum after tobacco smoke poisoning, which by the end of the experiment significantly exceeded the level of rats of adult and senile age. This suggests that immature rats are more sensitive to exposure to tobacco smoke.

Key words: tobacco smoke; white rats; inflammatory processes; cytolytic processes.

тивності внутрішньоклітинних ензимів у клітині та поза її межами, оскільки в нормі лише незначна їх кількість знаходиться в сироватці крові. Рівень активності ензимів корелює зі ступенем ушкодження мембран [15].

Відомо, що у мембранах біліарних шляхів печінки локалізуються гаммаглутамілтранспептидаза (ГГТП) та лужна фросоратаза (ЛФ). ГГТП зв'язана з епітелієм внутрішньопечінкових жовчних проток [16], ЛФ із плазматичною мембраною епітелію жовчовивідних шляхів та гепатоцитів. ЛФ $є$ органоспецифічним ензимом для печінки, зростання якого $є$ типовою ознакою холестазу, що супроводжується проявами запальних процесів, цитолізом та застоєм жовчі в жовчних капілярах і протоках [17]. Все це разом вносить свою частку в загальний ендогенний токсикоз та активність запальних процесів за потрапляння до організму ксенобіотиків.

Метою дослідження було з'ясувати вплив тютюнового диму на розвиток запалення та проникність клітинних мембран у щурів різного віку за тютюнової інтоксикації.

\section{МАТЕРІАЛИ I МЕТОДИ}

Досліди проведені на білих щурах-самцях, яких утримували на стандартному раціоні віварію Тернопільського національного медичного університету імені І. Я. Горбачевського МОЗ України. Щурів поділили на три вікові групи: статевонезрілі 3 масою тіла 60-80 г (3-місячного віку), статево- 
зрілі з масою тіла 180-200 г (12-місячного віку) та старечого віку - $з$ масою тіла 300-350 г (18-місячного віку).

Модель залежності від хронічної дії тютюнового диму створювали за допомогою герметичної камери об'ємом 30 літрів, що дозволило щоденно піддавати тварин дії токсиканта. Тютюновий дим, що утворювався від горіння 6 сигарет «Прима срібна (синя)» із вмістом 0,6 мг нікотину та 8 мг смоли; виробник АТ «Імеріал Табакко Продакшин Україна» ДСТУ ГОСТ 3935:2004, через отвори у камері подавався всередину. В камері одночасно знаходилось 6 тварин упродовж 6 хв. Щури контрольної групи також знаходились упродовж 6 хв у герметичній камері, але не підлягали дії тютюнового диму [18].

Через 15; 30 та 45 діб від початку ураження тварин тютюновим димом, їх виводили із експерименту шляхом евтаназії під тіопенталовим наркозом.

Матеріалом дослідження були гомогенат печінки та сироватка крові. Кров забирали із серця тварин, яку центриоругували при частоті обертання 1100 g упродовж 30 хв. Отриману сироватку крові (надосадову рідину) використовували для проведення досліджень. Відібрані органи (250 мг) використовували для отримання гомогенату за допомогою гомогенізатора магнітного Silent Crusher S після попередньої перфузії із 2,5 мл фрізіологічного розчину.

У сироватці крові визначали вміст СРП із використанням турбідометричного методу [19], в сироватці крові та гомогенаті печінки визначали активність ЛФ [20] та ГГТП [20].

Обробку статистичних даних виконували за допомогою пакета програмного забезпечення SPSS22 [21]. Розподіл даних аналізується за критерієм нормальності Колмогорова - Смірнова. Отримані значення мали параметричний розподіл, тому різниця між групами була проаналізована відповідно до t-критерію Стьюдента та непараметричного критерію Вілкоксона для зв'язаних вибірок. Х2-критерій використали для оцінки різниці між категоріальними даними. Різниця значень ймовірності була $p \geq 0,95$ (рівень значимості р). Розбіжності вважалися вірогідними при $\mathrm{p} \leq 0,05$.

\section{РЕЗУЛЬТАТИ Й ОБГОВОРЕННЯ}

Відомо, що тютюнокуріння - головний причинний фрактор розвитку запальних процесів у дихальних шляхах із подальшим поширенням запалення в усьому організмі $[2,6]$. Вплив тютюнового диму (ТД), особливо ультрадисперсних частинок фрракції, може активувати циркулюючі імуноцити в легенях, які потім вивільняють прозапальні цитокіни [22].

Найбільш специфічним і чутливим клініко-лабораторним індикатором запалення та некрозу $є$ С-реактивний протеїн. На відміну від короткоживучих цитокінів, для яких характерні добові коливання, вміст СРП досить стабільний завдяки його тривалому періоду напіввиведення з організму [23]. СРП є вторинним регулятором синдрому системної запальної відповіді та імуномодулятором, який активує фрункцію клітин багатьох тканин та систем. Після секреції СРП, маючи спорідненість до фросороліпідів, зв'язується з ліпопротеїнами дуже низької щільності та циркулює з ними в плазмі крові та міжклітинному середовищі. Модулюючи активність імунокомпетентних клітин і тромбоцитів, СРП фрактично здійснює зв'язок між різними ланками запального процесу [14].

В експериментах ми дослідили вміст СРП у сироватці крові щурів як маркера гострої фрази запального процесу.

Тривале отруєння ТД призвело до підвищення у сироватці крові щурів усіх вікових груп вмісту СРП (табл. 1).

Найбільшого значення в усі терміни дослідження досяг вміст СРП у сироватці крові щурів старечого віку й перевищував норму через 15 діб ураження на $50 \%$, через 30 діб - на $89 \%$ і через 45 діб від початку експерименту - в 1,4 раза.

Отруєння ТД статевонезрілих щурів викликало різке підвищення у сироватці крові СРП залежно від терміну дослідження, вміст якого наприкінці експерименту в 2,1 раза був вищим від рівня контрольної групи тварин. У статевозрілих щурів цей показник перевищував рівень контрольних тварин на 104 \%.

Зареєстровані підвищені рівні СРП можуть бути діагностичним критерієм оцінки запальних процесів у курців та слугувати несприятливим прогностичним фрактором розвитку захворювання легень.

Таблиця 1. Вміст С-реактивного протеїну (мг/л) в сироватці крові щурів у динаміці ураження тютюновим димом $(\mathrm{M} \pm \mathrm{m} ; \mathrm{n}=72)$

\begin{tabular}{l|c|c|c}
\hline \multirow{2}{*}{ Термін дослідження, доба } & \multicolumn{3}{|c}{ Група дослідних тварин } \\
\cline { 2 - 4 } & статевонезрілі & статевозрілі & старечі \\
\hline Контрольні щури & $2,87 \pm 0,21$ & $2,12 \pm 0,16$ & $4,29 \pm 0,12$ \\
\hline 15 доба ТД & $4,05 \pm 0,21^{\star}$ & $2,70 \pm 0,25$ & $6,23 \pm 0,37^{\star}$ \\
\hline 30 доба ТД & $4,85 \pm 0,30^{\star}$ & $3,47 \pm 0,24^{\star}$ & $7,84 \pm 0,50^{\star}$ \\
\hline 45 доба ТД & $6,16 \pm 0,46^{\star}$ & $4,32 \pm 0,36^{\star}$ & \\
\hline
\end{tabular}

Примітка. * - вірогідні зміни між показником контрольних та уражених тютюновим димом тварин.

ISSN 2706-6282(print)

ISSN 2706-6290(online)
Вісник медичних і біологічних досліджень Bulletin of Medical and Biological Research
$3(9), 2021$ 
3 літератури відомо, що виражені розлади метаболізму, накопичення недоокиснених токсичних продуктів та активація процесів пероксидного окиснення ліпідів, які мають місце за тютюнової інтоксикації, призводять до активації мембранодеструктивних процесів, зростання ендотоксикозу та виникнення поліорганної недостатності [5, 24].

За умов ураження щурів ТД доцільно було дослідити активність лужної фроссратази - маркера функціонального стану печінки. Лужна фросфратаза - цинковмісний металопротеїн, який розщеплює ефріри ортофоосфатної кислоти 3 утворенням неорганічного фоссрору. Ензим розміщується в клітинах у зв'язаному з плазматичними мембранами стані.

Про ушкодження мембранних структур гепатоцитів свідчать результати досліджень органоспецифрічного ензиму (маркера холестазу) - лужної фоссратази в сироватці крові та гомогенаті печінки

Підтвердженням деструктивних процесів у гепатоцитах та зміни їх проникності $€$ зниження активності ЛФ у печінці. Встановлено зменшення даного показника у статевонезрілих щурів у всі терміни дослідження. Найбільш виражене зниження було наприкінці експерименту, коли активність ЛФ знизилась у 3 рази порівняно з контролем. У щурів старечого віку вірогідне зменшення спостерігали через 30 та 45 діб отруєння димом і становило 61 та $39 \%$ відповідно. Отруєння тютюновим димом статевозрілих щурів викликало тенденцію до зниження активності ЛФ у їх печінці, вірогідних змін не відмічено в жодний термін дослідження (табл. 2).

Зважаючи на те, що ЛФ є органоспецифічним ензимом печінки, зростання якого у сироватці крові $€$ типовою ознакою холестазу, одержані результати варто розглядати як підтвердження ураження гепатоцитів із проявами запальних процесів, цитолізом та застоєм жовчі в жовчних капілярах і протоках.
Суттєвих змін зазнавала активність ще одного органоспецифічного ензиму печінки (маркера некрозу) - гаммаглутамілтранспептидази.

ГГТП - мікросомальний ензим, що бере участь в обміні амінокислот, каталізуючи перенесення гаммаглутамінового залишку з пептиду (зазвичай глутатіону) на амінокислоту, інший пептид чи воду. Зростання активності ГГТП спостерігається при ураженннях гепатобіліарної системи (гепатитах, холестазі, холангіті), а також при жировому переродженні печінки. Підвищення активності ензиму викликають різні ксенобіотики, зокрема ліки, здатні активувати оксидазну активність мікросомальних ензимів, а також будь-який оксидативний стрес [25].

При дослідженні активності ГГТП, ензиму, важливого при детоксикації, синтезі лейкотрієнів і транспорті амінокислот, у сироватці щурів, уражених ТД, відмічено його підвищення (рис.).

Ми показали, що каталітична активність ГГТП у сироватці крові дослідних тварин перевищувала контрольні значення на завершальних етапах експерименту. В сироватці крові статевонезрілих щурів активність ензиму зросла на $90 \%$, порівняно 3 контрольними тваринами через 45 діб отруєння ТД, у статевозрілих - на 35 \%, в старечого віку - на $63 \%$.

Доцільним було визначити активність ГГТП у печінці щурів після ураження ТД (табл. 3).

Вірогідне зниження активності даного показника $(p \leq 0,05)$ відмічено у печінці статевонезрілих щурів через 30 та 45 діб від початку експерименту. В ці періоди активність ензиму знизилась до 75 та $67 \%$ відповідно. У статевозрілих та щурів старечого віку виражене зниження активності ГГТП у печінці було тільки в останній термін дослідження.

Отже, ураження щурів різних вікових груп тютюновим димом призводило до цитолізу гепатоцитів і зміни проникності плазматичних мембран, на що вказувало підвищення активності лужної фросоратази

Таблиця 2. Активність лужної фроссратази в сироватці крові (нмоль/л год) та печінці (нмоль/кг год) щурів у динаміці ураження тютюновим димом (M $\pm m ; n=72)$

\begin{tabular}{|c|c|c|c|}
\hline \multirow{2}{*}{ Термін дослідження, доба } & \multicolumn{3}{|c|}{ Група дослідних тварин } \\
\hline & статевонезрілі & статевозрілі & старечі \\
\hline \multicolumn{4}{|c|}{ Сироватка крові } \\
\hline Контрольні щури & $11,63 \pm 0,72$ & $12,78 \pm 1,25$ & $11,31 \pm 0,97$ \\
\hline 15 доба ТД & $13,44 \pm 0,95$ & $12,88 \pm 1,08$ & $18,34 \pm 1,57$ \\
\hline 30 доба ТД & $17,12 \pm 1,69 *$ & $14,21 \pm 1,33$ & $16,87 \pm 1,34^{*}$ \\
\hline 45 доба ТД & $21,61 \pm 2,08^{\star}$ & $18,79 \pm 1,80^{*}$ & $19,50 \pm 1,68^{*}$ \\
\hline \multicolumn{4}{|c|}{ Печінка } \\
\hline Контрольні щури & $15,35 \pm 1,10$ & $16,48 \pm 1,00$ & $16,11 \pm 1,23$ \\
\hline 15 доба ТД & $11,02 \pm 1,09 *$ & $14,32 \pm 1,27$ & $12,33 \pm 1,21$ \\
\hline 30 доба ТД & $9,45 \pm 0,88^{*}$ & $13,65 \pm 1,15$ & $9,91 \pm 0,97^{*}$ \\
\hline 45 доба ТД & $5,14 \pm 0,49^{*}$ & $12,74 \pm 1,10$ & $6,33 \pm 0,57^{*}$ \\
\hline
\end{tabular}

Примітка. *- вірогідні зміни між показником контрольних та уражених тютюновим димом тварин. 


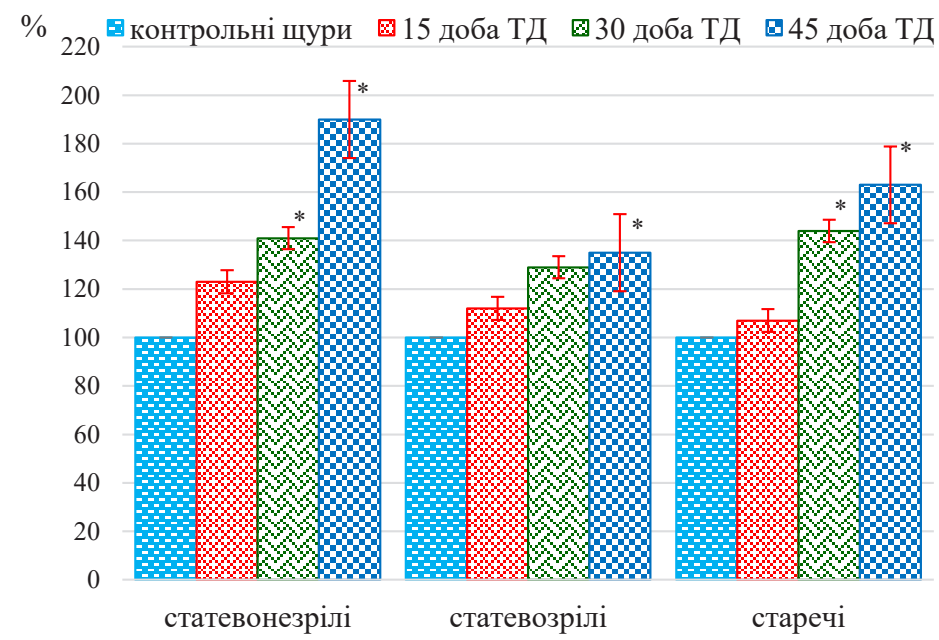

Рис. Активність гаммаглутамілтранспептидази у сироватці крові щурів різного віку після ураження тютюновим димом

Примітка. * - вірогідні зміни між показником контрольних та уражених тютюновим димом тварин.

Таблиця 3. Активність гаммаглутамілтранспептидази в печінці (мккат/кг) щурів у динаміці ураження тютюновим димом $(\mathrm{M} \pm \mathrm{m} ; \mathrm{n}=6)$

\begin{tabular}{l|c|c|c}
\hline \multirow{2}{*}{ Термін дослідження, доба } & \multicolumn{3}{|c}{ Група дослідних тварин } \\
\cline { 2 - 4 } & статевонезрілі & статевозрілі & старечі \\
\hline Контрольні щури & $1,74 \pm 0,11$ & $1,18 \pm 0,07$ & $1,47 \pm 0,13$ \\
\hline 15 доба ТД & $1,57 \pm 0,11$ & $1,11 \pm 0,09$ & $1,28 \pm 0,10$ \\
\hline 30 доба ТД & $1,31 \pm 0,11^{*}$ & $0,99 \pm 0,09$ & $1,01 \pm 0,09^{\star}$ \\
\hline 45 доба ТД & $1,17 \pm 0,12^{*}$ & $0,89 \pm 0,06^{*}$ & \\
\hline
\end{tabular}

Примітка. * - вірогідні зміни між показником контрольних та уражених тютюновим димом тварин.

та гаммаглутамілтранспептидази у сироватці крові та зниження їх у печінці.

\section{висновки}

1. Після 45-добового отруєння щурів тютюновим димом виявлено прогресуюче збільшення у сироватці крові вмісту С-реактивного протеїну, що свідчить про активацію запальних процесів упродовж експерименту. Найбільш виражені зміни раннього маркера запалення були у старечого віку щурів (вміст С-реактивного протеїну зростав до кінця експерименту в 1,4 раза).

\section{СПИСОК ЛІТЕРАТУРИ}

1. Балакірєєва О. М. Рівень поширення і тенденції вживання тютюну, алкогольних напоїв, наркотичних речовин серед учнівської молоді України / О. М. Балакірєва, Т. В. Бондар, Ю. П. Галіч // Укр. ін-т соц. дослідж. ім. О. Яременка. - К. : Обнова. - 2011. - 176 с.

2. Кваша Е. А. Медицинские аспекты табакокурения / Е. А. Кваша. - Здоров'я України. - 2010. - № 20 (249). - C. $40-41$.

3. Контроль над тютюном в Україні. Національний
2. Ураження щурів різних вікових груп тютюновим димом призводить до активації деструктивних процесів в організмі, що супроводжується підвищенням у сироватці крові та зниженням у печінці мембранозв'язаних ензимів - гаммаглутамілтранспептидази та лужної фоссратази. Підвищення активності лужної фроссратази у сироватці крові, уражених тютюновим димом щурів, свідчить про розвиток запальних процесів та холестазу в печінці. У статевонезрілих щурів проникність клітинних мембран для внутрішньоклітинних ензимів виявилась найвищою.

звіт. - К. : МОЗ України, Європейське регіональне бюро BOO3, 2012. - 128 c.

4. Пікас О. Б. Про стан куріння цигарок у сучасних умовах, його вплив на виникнення захворювань в організмі людини / О. Б. Пікас // Буковинський медичний вісник. - 2015. - № 76 (4). - С. 227-230.

5. Грищук Л. А. Динаміка перекисного окиснення ліпідів та антиоксидантного захисту в щурів за умов гострого ураження легень / Л. А. Грищук, М. І. Марущак // 
Туберкульоз, легеневі хвороби, ВІЛ-інфекція. - 2011. № 2 (05). - С. 16-20.

6. Лихацький П. Г. Розвиток нітрооксидативного стресу та запальних процесів у щурів різного віку, уражених тютюновим димом / П. Г. Лихацький, Л. С. Фіра // Світ медицини та біології. - 2017. - № 4 (62). - С. 145-149.

7. Марущак М. І. Встановлення кореляційних зв'язків між рівнем активних фрорм кисню, вмістом нейтрофрільних гранулоцитів та газовим складом крові при експериментальному гострому ураженні легень / М. І. Марущак // Науковий вісник Ужгородського університету, серія «Медицина». - 2012. - № 1 (43). - С. 9-12.

8. Блюм Н. Е. Особенности цитокинового баланса при хронической обструктивной болезни легких / Н. Е. Блюм, А. Р. Антонов, Р. Р. Асадуллина / Росс. мед. журн. - 2006. - № 14 (22). - С. 34-39.

9. Криницька І. Я. Особливості цитокінового профрілю крові щурів 3 модельованим гепатопульмональним синдромом / І. Я. Криницька, І. М. Кліщ, М.І.Куліцька // Клінічна та експериментальна патологія. - 2012. - № 4 (42). - C. 82-86.

10. Авдеев С. Н. С-реактивный белок - новый или старый маркер бронхолегочных инсекций / С. Н. Авдеев, Г. Е. Баймаканова // Атмосорера. Пульмонология и аллергология. - 2008. - № 4. - С. 26-32.

11. Мудра A. Є. NO-синтаза та прозапальні цитокіни при гострому токсичному гепатиті та за впливу модуляторів синтезу оксиду азоту / А. Є. Мудра // Наук. зап. Терноп. нац. пед. ун-ту. Сер. Біол. - 2014. - № 4(61). C. 141-147.

12. Вельков В. В. Прокальцитонин и С-реактивный белок в соовременной лабораторной диагностике / В. В. Вельков // Лабораторна діагностика. - 2010. № 2. - С. 39-76.

13. Владимирова С. Г. С-реактивный белок как маркер тяжести иноекционного процесса у больных острым миелоидным лейкозом при нейтропении / С. Г. Владимирова, Л. Н. Тарасова, О. Ю. Скольская [и др.] // Терапевтический архив. - 2013. - Т. 85, № 11. - С. 34-40.

14. Chandrashekara S. C-reactive protein: An inflammatory marker with specific role in physiology, pathology, and diagnosis / S. Chandrashekara // J. Rheumatol Clin. Immunol - 2014. - No. 2 (1). - P. 1-7.

\section{REFERENCES}

1. Balakireeva OM, Bondar TV, Galich YuP. [The level of distribution and trends in the use of tobacco, alcoholic beverages, narcotic substances among students of Ukraine]. Ukr inst sots dosl im O. Yaremenko. Kyiv: Obnova; 2011. Ukrainian.

2. Kvasha EA. [Medical aspects of tobacco smoking]. Zdorov Ukr. 2010;20(249): 40-1. Ukrainian.

3. Control over tobacco in Ukraine. National report [Контроль над тютюном в Україні. Національний звіт] Kyiv: Ministry of Health of Ukraine, European Regional Bureau of WHO; 2012. Ukrainian.

4. Pikas OB. [About the mill of cigars at the lucky minds, which is pouring into the body of people]. Bukovyn med visn. 2015;76(4): 227-30. Ukrainian.

5. Grischuk LA, Marushchak MI. [Dynamics of peroxide oxidation of lipids and antioxidant absorption in rats].
15. Розвиток цитолітичного синдрому в організмі щурів різного віку, уражених тютюновим димом / П. Г. Лихацький, Л. С. Фіра, Л. А. Бойко [та ін.] // Укр. журн. клін. та лаб. медицини. - 2017. - № 2 (12). - С. 12-19.

16. Hanigan M.H. Gamma-Glutamyl Transpeptidase: Redox Regulation and Drug Resistance / M. H. Hanigan // Adv. Cancer Res. - 2014. - No. 122. - P. 103-141.

17. Малахова М. Я. Эндогенная интоксикация как отражение компенсаторной перестройки обменных процессов в организме / М. Я. Малахова // Эффрерентная терапия. - 2000. - Т. 6, № 4. - С. 3-14.

18. Churg A. Animal models of cigarette smoke-induced chronic obstructive pulmonary disease / A. Churg, J. Wright // Expert. Rev. Respir. Med. - 2010. - No. 4 (6). - P. 723-734.

19. Анализ количественного определения уровня С-реактивного белка и прокальцитонина у пациентов с инфекционной патологией / К. М. Алибаева, Н. А. Бердиярова, Н. К. Мухамеджанова [и др.] // Вестник АГИУВ. - 2015. - № 1-2. - С. 36-40.

20. Влізло В. В. Лабораторні методи досліджень у біології, тваринництві та ветеринарній медицині / В. В. Влізло, Р. С. Федорук, І. Б. Ратич. - Львів : СПОлОМ, 2012. - 764 с

21. Jannot A. S. Citation bias favoring statistically significant studies was present in medical research / A. S. Jannot, T. Agoritsas, A. Gayet-Ageron // J. Clin. Epidemiol. - 2013. - No. 66 (3). - P. 296-301.

22. Hubeau C. Interleukin-6 neutralization alleviates pulmonary inflammation in mice exposed to cigarette smokeand poly(I:C) / C. Hubeau, J. E. Kubera, K. Masek-Hammerman // Clin. Sci.(Lond). - 2013. - No. 125. - P. 483-493.

23. Kaur M. C-reactive protein: A prognostic indicator / M. Kaur // International Journal of Applied and Basic Medical Research. -2017. - No. 7 (2). - P. 83-84.

24. Лотоцька С. В. Застосування ентеросорбенту «карболайн» при корекції змін вільнорадикального окиснення у хворих на хронічне обструктивне захворювання легень / С. В. Лотоцька // Здобутки клінічної і експериментальної медицини. - 2015. - № 2-3. - С. 96-98.

25. Луцкий М. А. Свободнорадикальное окисление липидов и белков - универсальный процесс жизнедеятельности организма / М. А. Луцкий // Усп. совр. естеств. - 2014. - № 126. - С. 24-28.

Tuberculos, lehen khvoroby, VIL-infekts. 2011;2 (05): 1620. Ukrainian

6. Likhatskiy PG, Fira LS. [Development of nitrooxidative stress and ignition processes in rats of the different ages treated of tobacco smoke]. Svit med i biol. 2017;4(62): 1459. Ukrainian.

7. Marushchak MI. [Establishment of correlative links in the presence of active forms of acidity, together with neutrophilic granulocytes and gas storage of blood in an experimental state of the art]. Nauk visn Uzhhorod univer "Med" ser. 2012;1(43): 9-12. Ukrainian.

8. Blum NYe, Antonov AR, Asadullina RR. [Features of the cytokine balance in chronic obstructive pulmonary disease]. Ros med zhurn. 2006;14(22): 34-9. Russian.

9. Krynytska IYa, I.M. Klich IM, Kulitska MI. [Peculiarities of cytokine profile of blood of rats with modeled 
hepatopulmonary syndrome]. Kiln i eksperym patol. 2012;4(42): 82-6. Ukrainian.

10. Avdeev SN, Baimakanova GE. [C-reactive protein - a new or old marker of bronchopulmonary infections]. Atmosfer. Pulmonol i alerhol. 2008;4: 26-32. Ukrainian.

11. Mudra AE. [NO-synthase and pro-inflammatory cytokines in acute toxic hepatitis and under the influence of nitric oxide synthesis modulators]. Nauk. zap. Ternopil. nat. ped. un-tu. Ser. Biol. 2014;4(61): 141-7. Ukrainian.

12. Velkov VV. [Procalcitonin and C-reactive protein in modern laboratory diagnostics]. Labor diahnost. 2010;2: 3976. Ukrainian.

13. Vladimirova SG, Tarasova LN, Skolskaya OYu, Cherepanova VV. [C-reactive protein as a marker of the severity of the infectious process in patients with acute myeloid leukemia with neutropenia]. Terapevt arkhiv. 2013;85(11): 34-40. Ukrainian.

14. Chandrashekara S. C-reactive protein: An inflammatory marker with specific role in physiology, pathology, and diagnosis. J Rheumatol Clin Immunol. 2014;2(1): 1-7.

15. Likhatsky PG, Fira LS, Boyko LA, Fedorovich UM. [Development of cytolytic syndrome in the organisms of shyurov in the growth of the disease, in the case of tobacco smoke]. Ukr zhurn klin i labor med. 2017;2(12): 12-9. Ukrainian.

16. Hanigan MH. Gamma-glutamyl eranspeptidase: Redox regulation and drug resistance. Adv Cancer Res. 2014;122: 103-41.

17. Malakhova MYa. [Endogenous intoxication as a reflection of compensatory restructuring of metabolic processes in the body]. Efferent terap. 2000;6(4): 3-14. Russian.

18. Churg A, Wright J. Animal models of cigarette smoke-induced chronic obstructive pulmonary disease. Expert Rev Respir Med. 2010;4(6): 723-34.

19. Alibaeva KM, Berdiyarova NA, Mukhamedzhanova NK, Maimakova AM, Nurahova AD. [Analysis of the quantitative determination of the level of C-reactive protein and procalcitonin in patients with infectious pathology]. Vestnik AGIUV. 2015;1-2: 36-40. Russian.

20. Vlizlo VV, Fedoruk RS, Ratich IB. Laboratory methods of dosage in biology, technical and veterinary medicine. [Лабораторні методи досліджень у біології, тваринництві та ветеринарній медицині] LVIV: COMPLETE; 2012. Ukrainian.

21. Jannot AS, Agoritsas T, Gayet-Ageron A. Citation bias favoring statistically significant studies was present in medical research. J Clin Epidemiol. 2013;66(3): 296-301.

22. Hubeau C, Kubera JE, Masek-Hammerman K. Interleukin-6 neutralization alleviates pulmonary inflammation in mice exposed to cigarette smoke and poly(I:C). Clin Sci (Lond). 2013;125: 483-93.

23. Kaur M. C-reactive protein: A prognostic indicator. International Journal of Applied and Basic Medical Research. 2017;7(2): 83-4.

24. Lototskaya SV. [The use of enterosorbent "carboline" in the correction of changes in free radical oxidation in patients with chronic obstructive pulmonary disease]. Zdobut kiln i eksperym med. 2015;32(3): 96-8. Ukrainian.

25. Lutskiy MA. [Free radical oxidation of lipids and proteins - universal process of vital activity of the body]. Usp sovr estetv. 2014;126: 24-8. Russian. 